\title{
Charcoal as a Fuel in the Ironmaking and Smelting Industries
}

\author{
Thomas J. Straka \\ Department of Forestry and Environmental Conservation, Clemson University, Clemson, SC, USA \\ Email: tstraka@clemson.edu
}

How to cite this paper: Straka, T. J. (2017). Charcoal as a Fuel in the Ironmaking and Smelting Industries. Advances in Historical Studies, 6, 56-64.

https://doi.org/10.4236/ahs.2017.61004

Received: January 20, 2017

Accepted: March 18, 2017

Published: March 21, 2017

Copyright $\odot 2017$ by author and Scientific Research Publishing Inc. This work is licensed under the Creative Commons Attribution International License (CC BY 4.0).

http://creativecommons.org/licenses/by/4.0/

\begin{abstract}
Charcoal has been used as a metallurgical fuel for thousands of years. In the United States it was the fuel of choice for ironmaking and the smelting of other metals for much of the nineteenth century, and an understanding of the basics of charcoal production is necessary for any historical description of those industries. Discussion of the technology and production process in charcoal making rarely addresses the fundamentals of the charcoal itself. Four key attributes of charcoal in terms of this historical context are described: charcoal characteristics, the carbonization process, measuring charcoal, and transporting charcoal.
\end{abstract}

\section{Keywords}

Charcoal, Ironmaking, Smelting, Fuel, Carbonization, Pyrolysis

\section{Introduction}

There has been much history written about the American ironmaking and smelting industries; this history usually at least mentions charcoal as the fuel for the early industrial period, occasionally attempts to explain why charcoal was the preferred fuel, and describes the technology used to produce it (Bining, 1973; Gordon, 1996; Hillstrom \& Hillstrom, 2005; Swank, 1892; Walker, 2000). Even local histories for small iron furnaces typically discuss the use of charcoal as fuel (Bennett, 2011; Jacob, 1999; Norris, 1964). The history of the science of charcoal production and the basic characteristics of charcoal are a necessary part of any discussion of the ironmaking and smelting industries and are sparsely covered in the literature. An earlier article in this journal examined historical charcoal production characteristics, but did not delve into the basics of charcoal itself (Straka, 2014). These basics are provided here as necessary insights for any historical review of these industries.

In the United States charcoal fuel for smelting centered on iron in the East 
and precious metals in the West. Ironmaking technology requires three ingredients: iron ore, a flux (limestone), and an efficient fuel. Until about 1840 the sole fuel for iron production in the United States was charcoal (Swank, 1892). Only after the Civil War did coal and coke gain significance as a fuel source. Even then, charcoal production increased in real terms until after World War I. The last charcoal iron blast furnace operated until 1945 (Shallenberg, 1975). Charcoal fueled the western smelters until late in the nineteenth century, as even when coal and coke became available, railroads slowly gained access to remote smelters (Fell, 2009; Page, Page, Straka, \& Thomas, 2015; Young \& Budy, 1979). It is this temporal aspect that makes charcoal so interesting; it is tied to the formative periods of industrial development in the United States and is vital to economic expansion of the nation.

This technical background will also be useful in environmental history research as there is an environmental aspect to charcoal production. It has been long-recognized as a source of deforestation and forest degradation, especially in tropical forests (Chidumayo \& Gumbo, 2013; Hosier, 1993). Charcoal is the primary urban fuel in parts of the world, especially Africa, and plays a crucial role in the energy cycle of developing economies. It may be more damaging to the environment than fuelwood and biomass fuels (mainly due to inefficient production techniques) and is often not competitive with other fuels in terms of price and energy efficiency (Kammen \& Lew, 2005). Charcoal production involves carbon, so there are implications for climate change (Sonter, Barrett, Moran, \& Soares-Filho, 2015).

Charcoal was more than the black fuel that went into the furnace. It was also the largest expense of a charcoal iron furnace and poor management of the fuel production phase of the operation could doom a furnace. In 1880 the charcoal iron industry formed a new association with a strong focus on their fuel; in describing themselves they noted:

The manager of a charcoal iron works must, ordinarily, be boss wood chopper and collier, mining and mechanical engineer, blast furnace manager, forge superintendent, ... In fact, be Jack-of-all-trades. He cannot follow the example of the manager who uses anthracite or coke for fuel, and order his supply by letter or through the ubiquitous commercial traveler. He must prepare his own fuel, and anticipate the want of his plant a year in advance. Wood cutting jobs are to be laid out, and watched to secure a cord of one hundred and twenty-eight cubic feet without too much preponderance of intersticial space, and precautions taken to prevent the labor of months being swept away by the bane of charcoal works-mountain fires. Then when the ground thaws, and colliers take the place of wood choppers, vigilance is required to secure a proper yield and good supply of product. Transportation for a bulky friable fuel must be provided, and care bestowed on stocking the fuel for the months when none is made. The various methods of making charcoal will bear thorough examination, and practical results compared (United States Association of Charcoal Iron Workers, 1880). 
The fundamentals of charcoal characteristics and production are laid out below in a nontechnical way to be useful to historians. They will allow for a better understanding of the basics of charcoal and a better interpretation of technical descriptions of its use.

\section{Charcoal Characteristics}

Charcoal is the solid residue that remains when wood is subjected to carbonization or pyrolysis. Wood is about $50 \%$ carbon, $44 \%$ oxygen, and $6 \%$ hydrogen. When wood is burned in an air-free environment, carbonization occurs and, after the water is driven out of the wood, the volatile matter is then driven out of the wood as gas (Emrich, 1985). What remains is charcoal that is roughly $65 \%$ $70 \%$ fixed carbon, with $30 \%$ volatile matter, and less than $5 \%$ ash. This is a fuel with a higher heating value than wood (Baker, 1983).

The volatile matter consists of organic compounds that vaporize as the charcoal is produced, leaving oils and tarry residue. Higher carbonization temperature produces less volatile matter, making charcoal that burns more cleanly, but is more friable or prone to crumbling (FAO Forestry Department, 1987).

What constitutes "good" charcoal? "Charcoal of good quality retains the grain of the wood; it is jet black in color with a shining luster in a fresh cross-section. It is sonorous with a metallic ring [when it strikes a hard object], and does not crush, nor does it soil the fingers. It floats in water, is a bad conductor of heat and electricity, and burns without flame" (Chaturvedi, 1943). Charcoal's form and structure is almost identical to wood (Toole, Lane, Arbogast, Smith, Peter, Locke, Beglinger, \& Erickson, 1961). Note that the form and structure of the wood used to produce the charcoal in Figure 1.

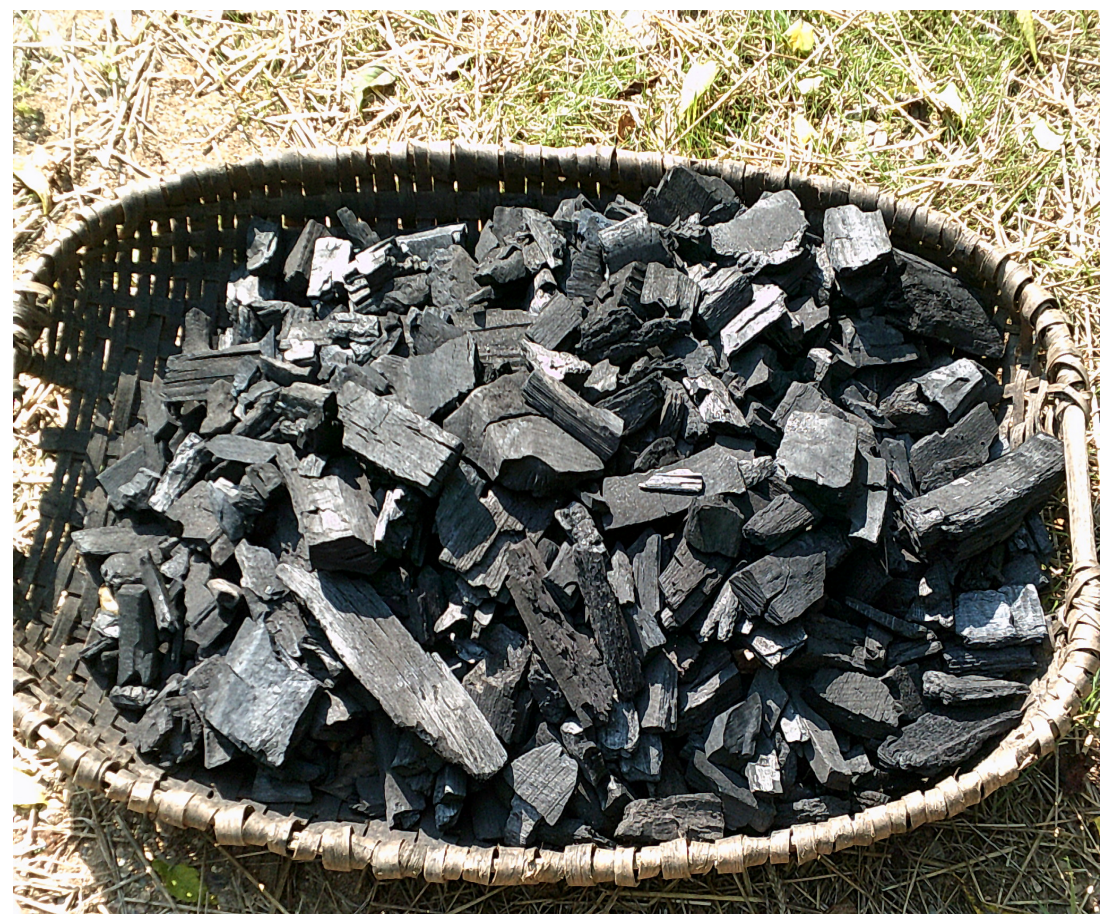

Figure 1. Charcoal from a charcoal pit, illustrating wood form and structure. 
There are key characteristics that affect charcoal's use in ironmaking. First, it burns hotter than wood at temperatures between $1450^{\circ} \mathrm{C}$ to $1760^{\circ} \mathrm{C}$ (Dieffenbach, 2003). Charcoal has a heat value of up to twice that of air-dried wood. Good quality charcoal concentrates heat value, burning cleanly and faster than mineral coal (Gordon, 1996). Second, fresh charcoal has very low moisture content, but rapidly absorbs moisture from the air. Poorly produced charcoal that retains excessive volatile matter will attract moisture and tend to shatter and produce fines (small pieces), reducing fuel value (FAO Forestry Department, 1987).

Third, properly prepared charcoal will weigh about one-third as much as wood and will have roughly one-half the volume of the original wood (Toole, Lane, Arbogast, Smith, Peter, Locke, Beglinger, \& Erickson, 1961), so it can be transported more easily and cheaply than wood (Birkinbine, 1879). Fourth, friability can be a problem; normal handling and transport can cause crumbling and reduce $5 \%-10 \%$ of the charcoal to fines (Toole, Lane, Arbogast, Smith, Peter, Locke, Beglinger, \& Erickson, 1961).

Fifth, compression strength of charcoal can limit the size of a furnace. The iron furnace contains iron ore, limestone, and fuel. Coal and coke can withstand the "burden" or weight better, increasing furnace productivity (FAO Forestry Department, 1987). Sixth, charcoal is the most expensive of the raw materials that go into the furnace (Gordon, 1996).

\section{The Carbonization Process}

Charcoal is produced in a charcoal pit or kiln. A charcoal pit is a carefully stacked wood pile burned on level ground ("pit" is a misnomer; all burning takes place above ground). A kiln is an "oven" made of stone or brick and is a permanent structure. In a charcoal pit the wood is covered with a layer of soil and is "burned" slowly with minimal air reaching the wood. In a kiln the structure itself limits the air. The process takes a week or longer.

Carbonization begins with a small amount of wood actually burning to ash in order to first dry the wood. At $270^{\circ} \mathrm{C}\left(518^{\circ} \mathrm{F}\right)$ the process becomes exothermic, or self-sustaining, and continues until only charcoal is remaining. The temperature of the charcoal pit will reach a maximum of $400^{\circ} \mathrm{C}\left(752^{\circ} \mathrm{F}\right)$. Charcoal is sometimes referred to as pure carbon, but this is not the case. Only in an enclosed kiln with outside heat will the fixed carbon increase above the $70 \%$ level. A temperature of $700^{\circ} \mathrm{C}\left(1292^{\circ} \mathrm{F}\right)$ will result in a fixed carbon content of $92 \%$ (FAO Forestry Department, 1987).

There are numerous factors that influence the rate of burning, affecting both charcoal quality and quantity produced (Brown, 1919). First, is the type of wood. Most species of wood can be used to make charcoal. Hard hardwood trees, like oak and hickory, are best, but softwoods, like pine, and soft hardwoods, like cottonwood and birch, make usable charcoal. Bark makes poor charcoal, so its use is minimized (Toole, Lane, Arbogast, Smith, Peter, Locke, Beglinger, \& Erickson, 1961). Second, size of wood pieces is a big factor, including length, 
thickness, regularity, and straightness of individual billets (sticks of wood). Large wood pieces carbonize more slowly than smaller ones (Svedelius, 1875). Third, wood condition is important. Decay, knots, and defects do not make good charcoal (FAO Forestry Department, 1985).

Fourth, moisture content of the wood placed in the charcoal pit impacts carbonization. Excess moisture must be evaporated or burned out of the wood before carbonization begins. So, ideally the wood used in the charcoal pit should be properly air-dried (Antal \& Grønli, 2003). Fifth, the condition of the ground where the pit is constructed is important. The ground needs to be perfectly dry, solid, level, and free from air drafts (Kemper, 1941). Sixth, the time of the year is also important. Charcoal is usually made in summer and early fall, after the wood cut from the previous winter has dried (Kemper, 1941). Seventh, weather conditions and temperature affect the rate of the burn. The pit needs more air during rainy, humid weather and less air during dry or windy days (Straka, 2014).

\section{Measuring Charcoal}

Historical accounts of ironmaking and smelting furnaces often discuss the charcoal fuel and, of course, measurements come into play. This can be complicated, because during the early history of the industries there was disagreement over exactly how charcoal should be measured (Birkinbine, 1880a). Charcoal was measured by the bushel (35.24 liters) or ton (0.91 metric ton), and sometimes even by the cord (3625 liters). The bushel was most common, but its definition varied from 35 to 47 liters (2150 to 2844 cubic inches) in volume, or from 5 to 10.2 kilograms (11 to 22.5 pounds) in weight. A cord is a measure of wood, not charcoal. However, the uncertainty of charcoal measurement caused some ironmasters to measure charcoal consumption in terms of cords of wood used to produce the fuel. One expert described the measurement of charcoal as "seemingly impossible of solution" (Birkinbine, 1880a).

An early charcoal burning text gave these generalizations: deciduous trees produce heavier wood than softwoods; younger trees produce lighter wood than older trees; trees felled in winter produce stronger charcoal than those felled in summer; and well-seasoned wood produces better charcoal than green wood (Svedelius, 1875). So the weight of charcoal may be a more difficult measure than that of volume, plus the weight of a bushel of charcoal still begs the question of bushel size in volume (Birkinbine, 1880b).

Purchasing charcoal by volume measure offered four advantages. First, brands (partly charred wood) and dirt were often included in the charcoal load and weigh more than charcoal for the same volume, so brands produced less impact on costs when measured by volume. Second, no water (due to high moisture content) was paid for. Third, transportation had a greater impact on reducing charcoal volume than weight. Fourth, there was no need for "dockage" for extra weight for things like mud on the wagon or wheels (Birkinbine, 1980b).

Purchasing charcoal by weight offered three advantages. First, lighter, softer, 
and bulkier charcoal was purchased at a lower cost than hard and compact charcoal. Second, weighed charcoal produced regularity in the blast furnace and lower fuel consumption per ton of product. Third, dirt or debris in the load is better accounted for by weight. The combination of the two methods might be preferred: purchase charcoal by volume (this does away for dockage for dirt, fines, dust, brands, water, or other defects) and then charging the furnace by weight, providing a uniformity of moisture content, carbon by weight, and improved furnace performance (Birkinbine, 1880b).

In 1882 the United States Association of Charcoal Iron Workers adopted standards for publishing in their journal. A bushel was to contain 40.1 liters ( 2478 cubic inches) and weigh 9.1 kilograms (20 pounds). The Association made an effort to secure legislation in the various states to adopt their standards and they were largely successful in the charcoal-producing states (Birkinbine, 1882). Gradually state legislatures adopted the Association standards (Birkinbine, 1885).

\section{Transporting Charcoal}

Charcoal was transported in charcoal wagons and later in railroad cars. Transportation affected charcoal quality. It was often the most significant component of charcoal making. In some situations transport of charcoal to the furnace exceeded the cost of purchasing, cutting, and hauling the wood to the charcoal pit, plus the charcoal burning itself. Some characteristics of charcoal can make it more difficult to transport; it is friable, cumbrous, costly to handle, easily absorbs moisture (adding to its weight), and has a propensity to reignite (Birkinbine, 1881).

Even after transport the charcoal was subject to degradation. Charcoal at the furnace was stored in a charcoal shed. At the shed the charcoal wagon draw boards were pulled and the charcoal dropped to the ground, allowing the wagon wheels to crush a portion of it. If the charcoal was to be immediately used, it was hauled to the furnace in wheelbarrows, or if it was to be stored in the charcoal shed, it would be forked and raked into charcoal baskets, and this tended to break up the charcoal. Wood supply problems and transportation problems could interact to require charcoal to be supplied from great distances (Birkinbine, 1881).

In 1881 a Pennsylvania furnace found it necessary to transport charcoal from its own kilns 531 kilometers ( 330 miles) by railroad. Rail transport resulted in a $16 \%$ decrease in volume, almost entirely due to the packing of charcoal. In contrast, when charcoal was transported by wagon directly from the pits (located only four to seven miles away) the decrease in volume was $26 \%$ (Potts, 1882). Transportation played a crucial role in defining how cost-effective charcoal could be as a fuel and poor handling of it in transit to the furnace could easily damage a furnace's profitability.

\section{Conclusion}

Charcoal was a fundamental aspect of the ironmaking and smelting industries. It 
provided the fuel that powered the technology involved. Historical descriptions of that industrial process commonly give minimal attention to that fuel, especially the basic characteristics of charcoal, the science of carbonization, and the measurement of the product. Those subjects are discussed above and provide detail that historians will find useful in addressing the technology used to produce the fuel for those industries.

Starting in about 1840 the American ironmaking industry started to shift from charcoal to coal or coke. This does not mean the use of charcoal as an industry fuel quickly declined. By 1850 half of iron production was from charcoal furnaces, but this statistic is deceptive. Charcoal iron production actually increased until 1890 and remained significant until after World War II. Even though coal furnace production was much greater than charcoal furnace production, overall production increased so much that charcoal iron production increased or remained strong for all of the nineteenth century. The decline in charcoal's proportionate share of iron production was due to changing technology (larger blast furnaces with increased heights and charcoal could not support the greater overburden) and price (new production centers required huge quantities of fuel that local forests could not support, resulting in greater fuel transportation costs). Charcoal iron furnaces contributed to American iron production well into the twentieth century (Baker, 1985).

Smelters did not only process iron ore. Charcoal remained a fuel of choice for many western smelters that processed precious metal ores. Many of those smelters were far removed from the railroads and coal supplies. So charcoal fueled many gold, silver, and lead furnaces during the same time period. The supply of charcoal as a fuel and the impact on American forests is fascinating history. This background on charcoal provides technical information that must be part of any discussion on the industries that processed America's ores.

\section{References}

Antal, M. J., \& Grønli, M. (2003). The Art, Science, and Technology of Charcoal Production. Industrial and Engineering Chemistry Research, 42, 1619-1640. https://doi.org/10.1021/ie0207919

Baker, A. J. (1983). Wood Fuel Properties and Fuel Products from Wood. In R. J. Obyc (Ed.), Proceedings of Fuelwood Management and Utilization Seminar (pp. 14-25). East Lansing, MI: Michigan State University. https://www.fpl.fs.fed.us/documnts/pdf1983/baker83a.pdf

Baker, A. J. (1985). Charcoal Industry in the USA. In National Timber Research Institute (Ed.), Symposium on Forest Products Research International-Achievements and the Future (Volume 5, 15 p). Pretoria: South African Council for Scientific and Industrial Research. https://www.fpl.fs.fed.us/documnts/pdf1985/baker85a.pdf

Bennett, J. R. (2011). Tannehill Ironworks. Charleston, SC: Arcadia Publishing.

Bining, A. C. (1973). Pennsylvania Iron Manufacture in the Eighteen Century (2nd ed.). Harrisburg, PA: Pennsylvania Historical and Museum Commission.

Birkinbine, J. (1879). The Production of Charcoal for Iron Works. Transactions of the American Institute of Mining Engineers, 7, 149-158.

https://babel.hathitrust.org/cgi/pt?id=hvd.32044102927183;view=1up;seq=11 
Birkinbine, J. (1880a). A Bushel of Charcoal. Journal of the United States Association of Charcoal Iron Workers, 1 , No. 1, 27-31.

http://quod.lib.umich.edu/cgi/t/text/text-idx?c=moajrnl;cc=moajrnl;view=toc;idno=A $\underline{\mathrm{HJ}} 4772.0001 .001$

Birkinbine, J. (1880b). A Bushel of Charcoal, II, (by Weight). Journal of the United States Association of Charcoal Iron Workers, 1, No. 1, 12-17.

http://quod.lib.umich.edu/cgi/t/text/text-idx?c=moajrnl;cc=moajrnl;view=toc;idno=A HJ4772.0001.001

Birkinbine, J. (1881). Transportation of Charcoal. Journal of the United States Association of Charcoal Iron Workers, 2, 136-139.

http://quod.lib.umich.edu/cgi/t/text/text-idx?c=moajrnl;cc=moajrnl;view=toc;idno=A HJ4772.0001.002

Birkinbine, J. (1882). Resolution of the United States Association of Charcoal Iron Workers. Journal of the United States Association of Charcoal Iron Workers, 3, 343. http://quod.lib.umich.edu/cgi/t/text/text-idx?c=moajrnl;cc=moajrnl;view=toc;idno=A HJ4772.0001.003

Birkinbine, J. (1885). Measuring Charcoal. Journal of the Unites States Association of Charcoal Iron Workers, 6, 335-336.

http://quod.lib.umich.edu/cgi/t/text/text-idx?c=moajrnl;cc=moajrnl;view=toc;idno=A $\underline{\mathrm{HJ}} 4772.0001 .006$

Brown, N. C. (1919). Forest Products: Their Manufacture and Use (pp. 235-247). New York: John Wiley and Sons Inc.

Chaturvedi, M. D. (1943). The Chinese Charcoal Kiln. The Indian Forester, 69, 75-79.

Chidumayo, E. N., \& Gumbo, D. J. (2013). The Environmental Impacts of Charcoal Production in Tropical Ecosystems of the World: A Synthesis. Energy for Sustainable Development, 17, 86-94. https://doi.org/10.1016/j.esd.2012.07.004

Dieffenbach, S. (2003). Cornwall Iron Furnace: Pennsylvania Trail of History Guide (pp. 11). Mechanicsville, PA: Stackpole Books.

Emrich, W. (1985). Handbook of Charcoal Making: The Traditional and Industrial Methods (pp. 12-15). Dordrecht: D Reidel Publishing Company.

https://doi.org/10.1007/978-94-017-0450-2

FAO Forestry Department (1985). Industrial Charcoal Making (pp. 4.1-4.2). FAO Forestry Paper 63, Rome: Food and Agriculture Organization of the United Nations. http://www.fao.org/docrep/x5555e/x5555e00.htm

FAO Forestry Department (1987). Simple Technologies for Charcoal Making (pp. 27-29, 101-108). FAO Forestry Paper 41, Rome: Food and Agriculture Organization of the United Nations. http://www.fao.org/docrep/X5328E/X5328E00.htm

Fell, J. E. (2009). Ores to Metal: The Rocky Mountain Smelting Industry. Boulder, CO: University Press of Colorado.

Gordon, R. B. (1996). American Iron, 1607-1900 (pp. 33-44, 90-124). Baltimore, MA: The Johns Hopkins University Press.

Hillstrom, K., \& Hillstrom, L. C. (Eds.). (2005). Industrial Revolution: Iron and Steel (pp. 163-172). Santa Barbara, CA: ABC-CLIO.

Hosier, R. H. (1993). Charcoal Production and Environmental Degradation: Environmental History, Selective Harvesting, and Post-Harvest Management. Energy Policy, 21, 491-509. https://doi.org/10.1016/0301-4215(93)90037-G

Jacob, S. F. (1999). The History of Joanna Furnace, 1791-1999: The History of a Berks County, Pennsylvania Charcoal Iron Furnace. Geigertown, PA: Hay Creek Valley His- 
torical Association.

Kammen, D. M., \& Lew, D. J. (2005). Review of Technologies for the Production and Use of Charcoal. Berkeley, CA: University of California, Energy and Resources Group \& Goldman School of Public Policy.

http://www.hedon.info/docs/Kammen-Lew-Charcoal-2005.pdf

Kemper, J. (1941). American Charcoal Making in the Era of the Cold-Blast Furnace (pp. 6-10). Popular Study Series History No. 14, Washington DC: National Park Service. https://www.nps.gov/parkhistory/online_books/popular/14/ps14-1.htm

Norris, J. D. (1964). Frontier Iron: The Maramec Iron Works, 1826-1876 (pp. 36-59). Madison, WI: The State Historical Society of Wisconsin.

Page, D. H., Page, S. E., Straka, T. J., \& Thomas, N. D. (2015). Charcoal and Its Role in Utah Mining History. Utah Historical Quarterly, 83, 20-37.

Potts, W. M. (1882). Weight of Charcoal and Loss by Railroad Transportation. Journal of the United States Association of Charcoal Iron Workers, 3, 327-328.

http://quod.lib.umich.edu/cgi/t/text/text-idx?c=moajrnl;cc=moajrnl;view=toc;idno=A HJ4772.0001.003

Shallenberg, R. H. (1975) Evolution, Adaptation and Survival: The Very Slow Death of the American Charcoal Iron Industry. Annals of Science, 32, 341-358. https://doi.org/10.1080/00033797500200331

Sonter, L. J., Barrett, D. J., Moran, C. J., \& Soares-Filho, B. S. (2015). Carbon Emissions Due to Deforestation for the Production of Charcoal Used in Brazil's Steel Industry. Nature Climate Change, 5, 359-363. https://doi.org/10.1038/nclimate2515

Straka, T. J. (2014). Historic Charcoal Production in the US and Forest Depletion: Development of Production Parameters. Advances in Historical Studies, 3, 104-114. https://doi.org/10.4236/ahs.2014.32010

Svedelius, G. (1875). Handbook for Charcoal Burners (pp. 20-25, 35-38). New York: John Willey and Son.

Swank, J. M. (1892). History of the Manufacture of Iron in All Ages, and Particularly in the United States from Colonial Times to 1891. Philadelphia, PA: The American Iron and Steel Association.

Toole, A. W., Lane, P. H., Arbogast, C., Smith, W. R., Peter, R., Locke, E. G., Beglinger, E., \& Erickson, E. C. O. (1961). Charcoal Production, Marketing, and Use (pp. 1-4). Report No. 2213, Madison, WI: USDA Forest Service, Forest Products Laboratory. https://www.fpl.fs.fed.us/documnts/fplr/fplr2213.pdf

United States Association of Charcoal Iron Workers (1880). Ourselves. Journal of the United States Association of Charcoal Iron Workers, 1, No. 1, 9-13.

Walker, J. E. (2000). Hopewell Village: The Dynamics of a Nineteenth-Century IronMaking Community (Eastern National ed.). Philadelphia, PA: University of Pennsylvania Press.

Young, J. A., \& Budy, J. D. (1979). Historical Use of Nevada's Pinyon-Juniper Woodlands. Journal of Forest History, 23, 112-121. https://doi.org/10.2307/4004663 
Submit or recommend next manuscript to SCIRP and we will provide best service for you:

Accepting pre-submission inquiries through Email, Facebook, LinkedIn, Twitter, etc. A wide selection of journals (inclusive of 9 subjects, more than 200 journals)

Providing 24-hour high-quality service

User-friendly online submission system

Fair and swift peer-review system

Efficient typesetting and proofreading procedure

Display of the result of downloads and visits, as well as the number of cited articles Maximum dissemination of your research work

Submit your manuscript at: http://papersubmission.scirp.org/

Or contact ahs@scirp.org 